\title{
Ueber den Sonnenfinsterniss-Cometen 1893 April 16.
}

\author{
Schreiben an den Herausgeber.
}

You have no doubt noticed a short paragraph which I inserted in the Publications A. S. P. (vol. VI, I 894, p. 144) relating to the discovery of a comet on the eclipse plates of the Lick Observatory (see Astronomy and Astro-Physics, April 1894, p. 307 , for a description of it). This comet is to be found on the British plates in Brazil, and in Africa, and its position has been independently verified by Messrs. Schaeberle, Barnard, Campbell and myself. We have just received by the kindness of Professor E. C. Pickering, copies of the plates taken by the Harvard College Observatory Expedition, under the direction of Professor W. H. Pickering, and the same comet is shown on the copies of their plates nos. 454,467 and 468 . We have not been able to obtain copies of the negatives of the French expeditions up to this time; but the evidence appears to be complete without them. This comet should, I presume, receive the designation of Comet I, I893, and I write to ask if you will not give it this name in the Astronomische Nachrichten. *) The moving object shown on the plates taken at four different stations appears to the eye like a nebula. The observations are probably not sufficient to show that it moves in a conic.

Mount Hamilton 1894 July 24.

Edward S. Holden.

Auszug aus zwei weiteren Schreiben vom 26 . und 30. Juli.

I see in the last »Observatory « (July I 894), which has just arrived here, that the English gentlemen have not been able to find Schaeberle's comet on their plates. The comet is there, nevertheless, and I will undertake to show it to anyone in Io seconds...

Professor Schaeberle has sent to the R. A. S. a couple of copies of negatives showing his comet (I) from a L.O. negative, (a) from a British negative; and I enclose for you similar copies. + ) The exact shape of the object is shown in Astronomy and Astro-Physics for April 1894 p. 307. The object is on 12 L. O. plates and 3 H. C. O. plates taken in Chile - and it is (less plainly) shown on 2 British plates in Brazil, and 3 British plates in Africa - only it has moved.

This object should have been independently discovered in the examination of the British plates; and certainly seen as soon as we. told them where to look for it. It fulfils the definition of a comet - except that no spectroscopic test has been applied.

*) Es wird nicht angehen, auch dem bisherigen Brauch widersprechen, diesen Cometen nachträglich als I893 I in die Register der berechneten Bahnen einzuführen. Er wird unter dem Namen »Comet, beobachtet während der Sonnenfinsterniss I893 April I6 unter den Cometenerscheinungen des Jahres 1893 aufgeführt werden müssen. Auch der in Sohag während der totalen Sonnenfinsterniss I882 Mai I6 photographirte Comet hat damals keine Nummer für die Einrangirung nach der Perihelzeit erhalten können. Kr.

†) Nach einer von uns angestellten Prüfung ist der Comet auf den von Prof. Holden gitigst übersandten Copien an den von Herrn Schaeberle angegebenen Stellen deutlich zu erkennen. Auf der britischen Platte ist allerdings die Helligkeit eine bedeutend geringere, doch ist auch hier sein Vorkommen unzweideutig.

\section{Ueber einen neuen veränderlichen Stern vom Algoltypus, Z Herculis. $1855.0: 17^{\mathrm{h}} 51^{\mathrm{m}} 34^{\mathrm{s}} 08+15^{\circ} 9^{\prime} 16^{\prime \prime} 4,1900.0: 17^{\mathrm{h}} 54^{\mathrm{m}} 30 \mathrm{~s} 26+15^{\circ} 8^{\prime} 35^{\prime \prime} 0$}

Schreiben von Dr. E. Hartwig, Director der Sternwarte in Bamberg, vom 20 . Sept.

"In der Potsdamer photometrischen Durchmusterung sind die Sterne Nr. 2404 und Nr. 2405 (BD. + I 5⒊309 und $+15^{\circ} .33 \mathrm{I}$ ) der Veränderlichkeit verdächtigt worden und sie wurden daher am ersten klaren Abend nach Empfang des schönen Werkes und von da an in verschiedenen durch die Witterung nur spärlich gebotenen bellen Nächten von mir mit den Sternen BD. + I $4^{\circ} \cdot 3378$ und BD. + $5^{\circ} \cdot 33^{\circ} \mathrm{r}$ verglichen, bis bei Eintritt beständigerer Witterung durch die Beobachtung an den zwei aufeinander folgenden Abenden des Io. und I I. September die Gewissheit entstand, dass bei dem Stern Nr. 2405 (BD. + I 53 3 I I ) Algoltypus vorläge, ohne dass das spärliche Material noch Sicherheit über die Periode gewährte. Am 14. September gelang dann die erste Beobachtung eines Minimum im abnehmenden und zunehmenden Lichte mit dem Ergebniss des Zeitpunktes $9^{\mathrm{h}} 39^{\mathrm{m}}$ M. Z. Bamberg für dessen Mitte bei einem Verweilen in demselben von 50 Minuten und dem weiteren Ergebniss der Dauer von 1 Tag 23 Stunden 55 Minuten 40 Secunden für die Periode bei Berücksichtigung einer Beobachtung vom 3 I. August, die zwar keine Minimalhelligkeit, aber auch nicht das hellste Licht ergeben hatte. Die Beobachtung vom r6. September zeigte nun, dass das auf dieses beobachtete Minimum vom I 4. September folgende Minimum nahe 4 Stunden früher als die Periode es verlangte, eingetreten sein musste, ohne dass aus den Beobachtungen mit Sicherheit sich der Betrag der Minimalhelligkeit ableiten liess, da nur der letzte Rest des aufsteigenden Lichtes von der Dämmerung an in die Nacht hinein noch beobachtet werden konnte. Ich bat deshalb am I 7. September die Centralstelle in Kiel um telegraphische Benachrichtigung*)

*) Dieselbe ist erfolgt. Ktz. 